\title{
Assessment of carbon storage potential of forested wetland soils as affected by urbanization degree in two different physiographic provinces of Virginia, USA
}

Kathryn Ledford

George Mason University

Stephanie Schmidt

George Mason University

Changwoo Ahn ( $\square$ cahn@gmu.edu )

George Mason University https://orcid.org/0000-0002-0747-2903

\section{Research Article}

Keywords: Wetlands, Soil Carbon, Carbon Stocks, Bulk density, Soil moisture, Urbanization, Physiography

Posted Date: March 19th, 2021

DOI: https://doi.org/10.21203/rs.3.rs-184678/v1

License: (a) (1) This work is licensed under a Creative Commons Attribution 4.0 International License. Read Full License 


\section{Abstract}

This study assessed carbon storage potential in terms of total carbon (TC) and total carbon stocks (TC stocks) in soils of four forested wetlands in Northern Virginia along with associated soil physicochemistry [e.g., soil pH, bulk density $\left(D_{b}\right)$, and gravimetric soil moisture (GSM)]. The study sites were selected across two vastly different degrees of urbanization (urban [U]; non-urban $[\mathrm{N}]$ ) and the two main physiographic provinces of the region (Piedmont; Coastal Plain). Soils were sampled and analyzed at three depth intervals $(0-10 \mathrm{~cm} ; 10-$ $20 \mathrm{~cm} ; 20-30 \mathrm{~cm})$. No significant differences were found in TC $(3.07 \pm 0.31 \%$ [U]; $3.82 \pm 0.40 \%$; [N]) or TC stocks $\left(2.81 \pm 0.35 \mathrm{~kg} \cdot \mathrm{m}^{-2}[\mathrm{U}] ; 3.58 \pm 0.28 \mathrm{~kg} \cdot \mathrm{m}^{-2}[\mathrm{~N}]\right)$ between urbanization degrees $(p>0.05)$. There was no significant difference in TC stocks by physiographic province $(p>0.05)$, however, Coastal Plain wetland soils had higher TC than the Piedmont wetlands $(4.32 \pm 0.41 \% ; 2.57 \pm 0.22 \%, p<0.05)$. $D_{b}$ and GSM were significantly different along urbanization degree and physiography, and were highly correlated to TC, being able to estimate the total variability of TC to a significant degree $\left(R^{2}=0.39\right.$ and $R^{2}=0.47$, all $\left.p<0.05\right)$. The outcome shows that urban wetlands fairly mirror the carbon storage potential of non-urban wetlands and more likely so in the Coastal Plain than in the Piedmont, especially in their top $10 \mathrm{~cm}$ of soils. Further studies may be warranted across an urbanizing landscape to elucidate carbon storage potentials of urban wetlands that can combat urban carbon emissions.

\section{Introduction}

Urbanization has becoming a pressing environmental and social issue across the globe, as the outward growth of urban development into former natural and agricultural lands has had lasting impacts on natural ecosystem services. Within the Chesapeake Bay Watershed (CBW) of the Mid-Atlantic United States, for example, the impacts of urbanization on the loss of natural ecosystems like forests and forested wetlands have been palpable, with over $100 \mathrm{~km}^{2}$ disturbed between 2015 and 2018 (Dahl 2011; Fretwell et al. 1996; Homer et al. 2020; Johnson and Lichter 2020; Lacher et al. 2019; Scanes 2018; Vanderhoof et al. 2020). Despite such losses, urban-specific environmental problems-specifically, high atmospheric greenhouse gas concentrations-have been addressed in part by prioritizing urban green spaces like urban forests and wetlands (Bae and Ryu 2015; Pulighe et al. 2016; Säynäjoki et al. 2018; Xue et al. 2019). In the CBW, forested wetlands are particularly ingrained into the urban ecosystem and are used by planners, developers, and stormwater and wildlife managers to provide recreational space, encourage biodiversity, purify water, and/or control urban flooding (Ahn and Schmidt 2019; Duan et al. 2020; Faller and McCleery 2017; Palta et al. 2017; Pasterski et al. 2020; Stefanakis 2019). Documented with non-wetland urban soils, wet forest and forested wetland soils in urban areas represent key opportunities to store large carbon pools, or carbon stocks, due to the slowed decomposition rates of organic matter that occur under saturated conditions (Canedoli et al. 2020; Golubiewski 2006; Mitsch and Gosselink 2015; Pouyat et al. 2006). Urban forested wetlands are thus unique opportunities to mitigate climate change through carbon storage within soil profiles.

Hydric wetland soils are of particular interest in urban environments because of their carbon storage potential is inexorably impacted by urbanization-induced changes to ecosystem functioning. Wetland soil is where many wetland biogeochemical transformations occur and is the primary storage location of available nutrients (Mitsch and Gosselink 2015). Urban wetland carbon stocks are of particular importance with 
ongoing climate change and are the primary focus of many urban wetland studies (Gao et al. 2011; Fennessy et al. 2018; Hansen and Nestlerode 2014; Lal 2004; Maietta et al. 2019; Trettin et al. 2006). Urban wet forests and forested wetlands typically have high carbon stocks compared to other urban ecosystems, with estimates ranging from 5.5 to $10.2 \mathrm{~kg} \cdot \mathrm{m}^{-2}$ for mixed urban forests and 5.5 to $14.0 \mathrm{~kg} \cdot \mathrm{m}^{-2}$ for urban wetlands, with restored and reforested soils hosting less carbon than their natural counterparts (Bae and Ryu 2015; Nave et al. 2019); however, land use disruptions common in urban development are known to impact soil carbon pools (Canedoli et al. 2020; Fennessy et al. 2018; Philips et al. 2016; Pouyat et al. 2006; Xiong et al. 2014). Total carbon stocks, including both soil inorganic carbon and soil organic carbon in a wetland, can indicate how effective a site is at accumulating and storing carbon (Canedoli et al. 2020; Lal 2004).

Estimating carbon stocks of forested wetlands in urbanized watersheds is an important step in relying on them for carbon storage strategies but requires knowledge of the singular and combined relationships between soil carbon and characteristics of urbanization, hydrology and soil physicochemistry. Alone, urbanization impacts on hydrology have been well documented, including increased runoff and flooding and decreased evapotranspiration due to impervious surfaces; these changes are known to significantly impact wetland development and functioning within an urban watershed (Botkin and Beveridge 1997; Reinelt et al. 1998; Sunde et al. 2018). Wetland soils can be changed either directly through development- e.g., drainageor indirectly from water flow changes-e.g., a disconnect from upstream water sources, or severe flooding (Bartholomew et al. 2019; Leeds et al. 2009; Little-Devito et al. 2019; Palta et al. 2014; Pasterski et al. 2020). Disruption of urban wetland soils can lead to the release of its large carbon reservoirs, but the risk of carbon release varies by wetland type (Chmura et al. 2003; Davidson and Janssens 2006; Holmquist et al. 2018; Mitsch and Gosselink 2015; Tarnocai 2006; Trettin et al. 2006). While efforts to quantify and track carbon storage potential within the context of urbanization have provided useful insight, high heterogeneity across geographic areas and even within study sites requires carbon stocks to be investigated within specific areas of interest.

Heterogeneity in landscape geology, geomorphology, physiography, and overall soil properties are known to impact hydric soil functioning and should be studied to provide context to a study on urbanization on a regional scale (Axt and Walbridge 1999; Pouyat et al. 2006; Wang et al. 2017). Wetlands in the Piedmont and Coastal Plain physiographic provinces of the eastern United States have distinct distribution patterns, hydrologic regimes, and soil series (Heath 1984; National Water Summary Wetland Resources 1996). Thus, TC stocks $\left(\mathrm{kg} \cdot \mathrm{m}^{-2}\right)$ of these two physiographic provinces could be significantly different based on distinct soil characteristics. Furthermore, physicochemical properties such as $\mathrm{D}_{\mathrm{b}}, \mathrm{pH}$, and GSM are known to be predictors of wetland functions and carbon biogeochemistry such that soil functional properties like carbon storage potential (i.e., TC stocks) are often studied through the measurement of various soil physicochemical properties (Ahn and Schmidt 2019; Ehrenfeld et al. 2003; Moser et al. 2007; Wahlroos et al. 2015; Yang et al. 2001). However, research linking these properties to urbanization while also teasing apart the footprints of physiography is lacking (Ahn and Jones 2013; Collins and Kuehl 2001; Cui et al. 2005; Dee and Ahn 2012; Gustave et al. 2019; Gutknecht et al. 2006; Hartman et al. 2008; Keller and Medvedeff 2016;).

Northern Virginia (NOVA), a region of the Washington, D.C. metropolitan area and the CBW, is home to many forested wetlands scattered across the urbanized landscape between its two physiographic provinces, the Piedmont $(\mathrm{P})$ and Coastal Plain (CP). Given conversion of many natural habitats into urban areas (Painter 
2018), the region provides a promising scene to study urban wetland soils within the context of physiography and soil properties. While high extents of impervious surface coverage have ultimately changed the hydrologic regime of the area, forested wetlands in NOVA may hold significant carbon storage potentials as demonstrated by other urban forested wetlands (Bae and Ryu 2015; Pouyat et al. 2006).

This study aimed to assess carbon storage potentials of soils in four forested wetlands across NOVA's Piedmont and Coastal Plain under two vastly different degrees of urbanization. It includes the characterization and comparison of soil physicochemical properties $\left(\mathrm{D}_{\mathrm{b}}, \mathrm{GSM}\right.$, and $\left.\mathrm{pH}\right)$ as well as carbon and nutrient contents [TC, TC stock, TN (total nitrogen)]. The results of the study were also compared with those previously assessed through a literature review of studies between 1990 to 2020, focusing on similar types of freshwater wetlands.

\section{Methods}

\section{Site Descriptions}

Field research was carried out in 2020 at four NOVA forested wetlands, selected to be balanced across two physiographic provinces-Piedmont $(\mathrm{P})$ and Coastal Plain (CP)-and two degrees of urbanization-nonurbanized (N) and urbanized (U) (Fig. 1) (Table 1). Urbanization was classified using the percent impervious surface cover (\% ISC) of each site's respective local watershed, where thresholds of ISC $<5 \%$ and ISC $>20 \%$ were used for identifying non-urbanized and urbanized watersheds, respectively. Sites include Elizabeth Hartwell Mason Neck National Wildlife Refuge (CP - N; ISC = 0.11\%), Algonkian Regional Park (P - U; ISC = $26.2 \%$ ), Banshee Reeks Nature Preserve ( $\mathrm{P}-\mathrm{N}$; ISC = 0.74\%), and Julie J. Metz Wetlands Bank (CP - U; ISC = 24.9\%) (Fig. 1). Each wetland site was sampled at 5 plots spaced at least $20 \mathrm{~m}$ apart. Table 1 describes the geomorphology, dominant soil, vegetation community, and watershed of the four sites. 
Table 1

Site setting as described by landscape, site, and wetland properties

\begin{tabular}{|c|c|c|c|c|}
\hline & $\begin{array}{l}\text { Algonkian Regional Park } \\
\text { (ARP) }\end{array}$ & Banshee Reeks (BR) & $\begin{array}{l}\text { Julie J. Metz } \\
\text { - Neabsco } \\
\text { Creek (JJM) }\end{array}$ & $\begin{array}{l}\text { Mason Neck } \\
(\mathrm{MN})\end{array}$ \\
\hline $\begin{array}{l}\text { Watershed } \\
\text { Name }\end{array}$ & Sugarland Run & $\begin{array}{l}\text { Big Branch - Goose } \\
\text { Creek }\end{array}$ & $\begin{array}{l}\text { Neabsco } \\
\text { Creek }\end{array}$ & $\begin{array}{l}\text { Occoquan } \\
\text { Bay - } \\
\text { Potomac } \\
\text { River }\end{array}$ \\
\hline $\begin{array}{l}\% \text { Impervious } \\
\text { Surface Cover }{ }^{1}\end{array}$ & 26.2\% (urbanized, U) & $\begin{array}{l}0.7 \% \text { (non-urbanized, } \\
\mathrm{N})\end{array}$ & $\begin{array}{l}24.9 \% \\
\text { (urbanized, } \\
\text { U) }\end{array}$ & $\begin{array}{l}0.1 \%(\text { non- } \\
\text { urbanized, N) }\end{array}$ \\
\hline $\begin{array}{l}\text { Physiographic } \\
\text { Province }\end{array}$ & Piedmont $(P)$ & Piedmont $(P)$ & $\begin{array}{l}\text { Coastal } \\
\text { Plain (CP) }\end{array}$ & $\begin{array}{l}\text { Coastal Plain } \\
(\mathrm{CP})\end{array}$ \\
\hline Geomorphology & $\begin{array}{l}\text { Drainageways, } \\
\text { floodplains, terraces }\end{array}$ & $\begin{array}{l}\text { Drainageways, } \\
\text { floodplains }\end{array}$ & $\begin{array}{l}\text { Terraces, } \\
\text { floodplains }\end{array}$ & $\begin{array}{l}\text { Fluvomarine } \\
\text { terraces, } \\
\text { interfluves, } \\
\text { drainageways }\end{array}$ \\
\hline $\begin{array}{l}\text { Nonhydric soil } \\
\text { series }\end{array}$ & $\begin{array}{l}\text { Linside, Huntington silt } \\
\text { loams }\end{array}$ & $\begin{array}{l}\text { Leedsville cobbly silt } \\
\text { loam } \\
\text { Oatlands gravelly silt } \\
\text { loam } \\
\text { Manassas silt loam }\end{array}$ & $\begin{array}{l}\text { Dumfries } \\
\text { sandy loam } \\
\text { Lunt loam }\end{array}$ & $\begin{array}{l}\text { Gunston, } \\
\text { Matapeake } \\
\text { silt loams } \\
\text { Mattapex } \\
\text { loam }\end{array}$ \\
\hline $\begin{array}{l}\text { Hydric soil } \\
\text { series }\end{array}$ & Kinkora-Delanco complex & $\begin{array}{l}\text { Codorus, Albano, and } \\
\text { Hatboro silt loams }\end{array}$ & $\begin{array}{l}\text { Featherstone } \\
\text { mucky silt } \\
\text { loam } \\
\text { Hatboro- } \\
\text { Codorus silt } \\
\text { loam }\end{array}$ & $\begin{array}{l}\text { Elbert and } \\
\text { Elkton silt } \\
\text { loams }\end{array}$ \\
\hline $\begin{array}{l}\text { Major } \\
\text { Vegetation } \\
\text { community }\end{array}$ & $\begin{array}{l}\text { Black walnut and oak } \\
\text { forested floodplains; } \\
\text { freshwater forested } \\
\text { wetlands; freshwater } \\
\text { emergent wetland }\end{array}$ & $\begin{array}{l}\text { Hardwood forests, } \\
\text { riparian zones, } \\
\text { wetlands, \& Mountain- } \\
\text { Piedmont basic } \\
\text { seepage swamp }\end{array}$ & $\begin{array}{l}\text { Forested, } \\
\text { scrub, and } \\
\text { emergent } \\
\text { wetland } \\
\text { communities }\end{array}$ & $\begin{array}{l}\text { hardwood } \\
\text { oak- hickory } \\
\text { forest, } \\
\text { palustrine } \\
\text { forested } \\
\text { wetland }\end{array}$ \\
\hline
\end{tabular}

Algonkian Regional Park and Banshee Reeks Nature Preserve reside in the Virginia Piedmont. Algonkian Regional Park (ARP) is an 838-acre public park located along the Potomac River in Loudoun County, Virginia $\left(39^{\circ} 59^{\prime} 9.19^{\prime \prime} \mathrm{N}, 77^{\circ} 37^{\prime} 36.15^{\prime \prime} \mathrm{W}\right)$. ARP plots occur along the Sanctuary Trail, a primarily unpaved two-mile trail that goes through 30 acres of less disturbed wetlands on Lowe's Island (NOVA 2020). Sample plots occur within freshwater forested wetlands and at the fringes of a freshwater emergent wetland dominated by the nonhydric Linside and Huntington silt loams as well as the hydric Kinkora-Delanco complex (Table 1). Water 
inputs include overland flow from the Potomac River, overland flow and groundwater connection with nearby emergent wetlands, and precipitation. Water tables range from $0 \mathrm{~cm}$ near emergent habitat and reach $60 \mathrm{~cm}$ within forested floodplains (US Fish and Wildlife Service, 2010). Banshee Reeks Nature Preserve (BR) is a 695acre preserve located in Loudoun County, Virginia adjacent to Goose Creek (39 $\left.39^{\circ} 73.4^{\prime \prime} \mathrm{N}, 77^{\circ} 59^{\prime} 17.35^{\prime \prime} \mathrm{E}\right)$. While BR was a farm through the early 19th century, a large portion of the preserve is still forested and has minimal urban developments (FBRNP 2020). Vegetation communities are primarily hardwood forests and also include riparian wetlands and a Mountain-Piedmont basic seepage swamp. BR is dominated by nonhydric Leedsville cobbly silt loam, Oatlands gravelly silt loam, and Manassas silt loam, as well as hydric silt loams including the Codorus, Albano, and Hatboro series plots experience occasional to frequent flooding or ponding and have dynamic hydrologic characteristics: some regions of the preserve are primarily influenced by groundwater connection with subsurface flow from Goose Creek, while others primarily receive inputs from precipitation and surface runoff near small tributaries of Goose Creek (Paul 2017).

Julie J. Metz Wetland Bankand Elizabeth Hartwell Mason Neck National Wildlife Refuge fall within Virginia's Coastal Plain. Adjacent to Neabsco Creek near the Potomac River, Julie J Metz Wetland Bank (JJM) (38 $36^{\circ} 23$ "N, 77 16'38" W) in Prince William County contains 200 acres of natural wetlands as well as 17 acres of wetland constructed in 1996 by Wetland Studies and Solutions, Inc. (WSSI). Forested, scrub, and emergent wetland communities dominate the site. Nonhydric soils include Dumfries sandy loam and Lunt loam; hydric soils include Featherstone mucky silt loam and Hatboro-Codorus silt loam. Several plots are flooded yearround; water inputs come from a range of hydrologic sources such as tidal freshwater, groundwater recharge, precipitation, and stream surface flow. Elizabeth Hartwell Mason Neck National Wildlife Refuge (MN) is a 2,227-acre habitat refuge on the Mason Neck peninsula in southern Fairfax County, Virginia, and touches the Occoquan Bay and the Potomac River ( $38^{\circ} 63^{\prime} 94.12^{\prime \prime}$ N, 77 19' 18.86" E) (U.S. Fish and Wildlife Service 2014). Plots belong to a hardwood forest and palustrine forested wetland with rolling microtopography consisting of high points (hummocks) and occasionally ponded low points (hollows) adjacent to a riverine freshwater marsh (Ahn et al. 2009). Hummocks are dominated by nonhydric soils like Gunston and Matapeake silt loams while hollows are dominated by hydric soils like Elbert and Elkton silt loams (Table 1).

\section{Soil Collection}

Soil cores were sampled at three subplots per plot $(n=60)$ using a soil auger modified from the design of Caldwell et al. (2005) and Giannopoulos et al. (2019). A PVC pipe soil auger was notched at the $10 \mathrm{~cm}, 20 \mathrm{~cm}$, and $30 \mathrm{~cm}$ to provide a method of separating cores into 10-cm intervals without damaging their integrity; the bottom of the auger was modified to have a saw tooth edge to ease soil removal. Limitations of the soil augers were accounted for (Craft et al. 2002, Ehrenfeld et al. 2003, Osland et al. 2012). Each core was removed in a single piece then divided into three depth intervals $-0 \mathrm{~cm}$ to $10 \mathrm{~cm}, 10 \mathrm{~cm}$ to $20 \mathrm{~cm}$, and $20 \mathrm{~cm}$ to $30 \mathrm{~cm}$-and photographed. Documented issues included heavy inundation at some sites, causing issues with the integrity of soil cores, and the rocky nature of the soil at JJM plot 2 (diameters $>5-10 \mathrm{~cm}$ ) such that all three of its subplots were sampled down to $20 \mathrm{~cm}$ instead of $30 \mathrm{~cm}$. 10-cm long samples $(n=180)$ were then wrapped in aluminum and placed in a prelabeled paper bag for weighing.

In addition to soil core samples collected for $\mathrm{D}_{\mathrm{b}}$, soil samples were collected to measure soil $\mathrm{pH}$ at three subplots per plot directly adjacent to $D_{b}$ subplots. A $2.5 \mathrm{~cm}$ diameter soil probe was pushed $\sim 30 \mathrm{~cm}$ into the 
soil then divided into three soil depth layers $-0 \mathrm{~cm}$ to $10 \mathrm{~cm}, 10 \mathrm{~cm}$ to $20 \mathrm{~cm}$, and $20 \mathrm{~cm}$ to $30 \mathrm{~cm}(\mathrm{n}=180)$. Samples were cleared of non-dissolvable debris (rocks, plant debris, etc.) and placed in a plastic bag for $\mathrm{pH}$ measurement.

\section{Analysis of soil physicochemistry and soil carbon}

For each 10 -cm soil probe samples $(n=180)$, a soil slurry was created on-site by adding distilled water to samples to create a 1:1 homogenous mixture, and a Hach IQ160 meter was used to measure the pH. After collection of soil core samples, wet masses were obtained using a Sartoruis Miras 2 scale with $5 \mathrm{~g}$ readability. Samples were placed into drying oven at $85^{\circ} \mathrm{C}$ to $105^{\circ} \mathrm{C}$ for at least 72 hours until a constant dry mass was achieved. The mass of aluminum foil and paper bag $(15 \mathrm{~g})$ was subtracted from measured wet and final dry masses. The volume of all the soil core samples was calculated as the volume of the soil probe $\left(453.656 \mathrm{~cm}^{3}\right.$, or $\pi \cdot 3.8 \mathrm{~cm}^{2} \cdot 10 \mathrm{~cm}$ ). GSM (\%) was calculated using the formula (wet mass-dry mass)/ (dry mass) x 100 . Finally, $\mathrm{D}_{\mathrm{b}}$ was calculated as dry mass $/ 453.656 \mathrm{~cm}^{3}$.

To prepare soils for elemental carbon and nitrogen analysis, dried soil core samples were ground using a mortar and pestle then passed through a $2 \mathrm{~mm}$ sieve at least three times to remove any non-soil debris (e.g., organic material or rocks) and to homogenize the samples. Dry-weight percentages for TC and TN were obtained for each sample using a Perkin-Elmer 2400 Series II CHNS/O Analyzer (Perkin-Elmer Corporation, Norwalk, CT, USA). To convert percentages into a carbon storage metric comparable between sites of different bulk densities, TC stocks $\left(\mathrm{kgC} \cdot \mathrm{m}^{-2}\right)$ were calculated from the TC and $\mathrm{D}_{\mathrm{b}}$ of the upper $10 \mathrm{~cm}$ of soil [TC stocks $\left.=\left(D_{b} \bullet 10,000\right) \cdot(T C / 100) / 1000\right]$, which is the most biogeochemically active layer of wetland soil (Ahn et al. 2009; Bruland and Richardson 2006).

\section{Data Analyses}

Statistical analyses were performed on $D_{b}, G S M, T C, T N$, and TC stocks using version 15 of JMPß (2019). To study overall physicochemical and carbon properties and also identify the effect of depth, data from 0 to 10 $\mathrm{cm}, 10$ to $20 \mathrm{~cm}$, and 20 to $30 \mathrm{~cm}$ were both separately assessed and pooled together to provide overall properties from 0 to $30 \mathrm{~cm}$. Additionally, to separate the most biogeochemically active layer of soil from remaining collected soil samples, 10 to $20 \mathrm{~cm}$ and 20 to $30 \mathrm{~cm}$ samples were pooled to provide a comparison between 0 to $10 \mathrm{~cm}$ and 10 to $30 \mathrm{~cm}$ samples.

Data was screened for normality and linearity through visual assessments and residual plots. Using a $a=0.05$ significance level, one-way analysis of variance (ANOVA) was performed for all soil physicochemical properties measured among the wetland sites. A three-way ANOVA was also performed using depth, physiographic province, and urbanization degree as factors. Fisher's LSD post-hoc test was conducted to determine the main effects of the three environmental factors. Linear correlation (i.e., Pearson correlation coefficients) was performed among all the soil physicochemical properties measured including soil carbon and nitrogen. Finally, bivariate regression coefficients were calculated between such soil physicochemical properties and TC and TC stocks using pooled data from all sites.

\section{Results And Discussion}




\section{Soil Physicochemistry across sites}

ANOVA revealed significant differences in all soil physicochemical and nutrient properties between sites when separated into $10-\mathrm{cm}$ intervals, and differences in all but $D_{b}$ when considering the top $30 \mathrm{~cm}$ overall $(p<0.05$; Table 2). JJM had the highest GSM out of all the sites ( $58.03 \pm 5.01 \%)$, corroborating high levels of inundation observed during collection at JJM for plots 3,4 , and 5 . In contrast, GSM was lowest at BR $(33.67 \pm 2.06 \%$; $<<$ $0.05)$, where several plots did not show signs of seasonal saturation despite being mapped as hydric by Loudoun County. Soil pH was significantly more acidic at MN $(4.67 \pm 0.03)$ than other sites, despite measuring $\sim 0.5 \mathrm{pH}$ units higher than that of previous research at the same sampling locations (Ahn et al. 2009) $(\mathrm{p}<$ $0.01)$. While overall $(0-30 \mathrm{~cm})$ soil $D_{b}$ did not significantly differ between sites, $D_{b}$ was consistently highest for the top $10 \mathrm{~cm}$ soil $\left(1.01 \pm 0.04 \mathrm{~g} \cdot \mathrm{cm}^{-3}\right)$ than other depth layers at all sites except JJM $(p<0.01)$ and generally increased with soil depth. Soil homogeneity at JJM suggests that hydrologic conditions at JJMcreated to have a biogeochemically active top $30 \mathrm{~cm}$-are the most stable of all sites down to $30 \mathrm{~cm}$ (Table 2). 
Table 2

Soil physicochemical properties measured for four sites along the depth scale reported as averages \pm standard errors. Total carbon stocks were calculated with the carbon values of the upper $10 \mathrm{~cm}$ of soil. GSM: gravimetric soil moisture; $\mathrm{D}_{\mathrm{b}}$ : bulk density; $\mathrm{TC}$ : soil total carbon content; $\mathrm{TN}$ : soil total nitrogen content; TC stock: soil total carbon stock.

\begin{tabular}{|c|c|c|c|c|c|}
\hline & Depth & ARP & BR & JJM & MN \\
\hline \multirow[t]{5}{*}{ GSM (\%) } & & $43.36 \pm 1.72^{a b}$ & $33.67 \pm 2.06^{b}$ & $58.03 \pm 5.01^{a}$ & $40.16 \pm 3.44^{b}$ \\
\hline & $\begin{array}{l}(0-30 \\
\mathrm{cm})\end{array}$ & & & & \\
\hline & $0-10 \mathrm{~cm}$ & $\begin{array}{l}55.27 \pm 2.52 \\
a b c\end{array}$ & $\begin{array}{l}42.85 \pm 3.02 \\
b c d\end{array}$ & $76.92 \pm 10.30^{a}$ & $\begin{array}{l}57.65 \pm 8.12 \\
a b\end{array}$ \\
\hline & $10-20 \mathrm{~cm}$ & $\begin{array}{l}38.06 \pm 1.75 \\
\text { bcd }\end{array}$ & $32.46 \pm 3.79 \mathrm{~cd}$ & $\begin{array}{l}44.09 \pm 6.65 \\
\text { bcd }\end{array}$ & $32.12 \pm 2.40^{c d}$ \\
\hline & $20-30 \mathrm{~cm}$ & $\begin{array}{l}36.74 \pm 1.52 \\
\text { bcd }\end{array}$ & $25.70 \pm 2.46^{d}$ & $\begin{array}{l}51.83 \pm 4.76 \\
\text { bcd }\end{array}$ & $30.71 \pm 2.65^{d}$ \\
\hline \multirow[t]{4}{*}{ Soil pH } & & $6.09 \pm 0.03^{a}$ & $6.11 \pm 0.08^{a}$ & $5.96 \pm 0.04^{a}$ & $4.67 \pm 0.03^{b}$ \\
\hline & $0-10 \mathrm{~cm}$ & $5.96 \pm 0.05^{a}$ & $6.14 \pm 0.08^{a}$ & $5.79 \pm 0.25^{a}$ & $4.68 \pm 0.08^{b}$ \\
\hline & $10-20 \mathrm{~cm}$ & $6.09 \pm 0.04^{a}$ & $6.13 \pm 0.15^{a}$ & $5.89 \pm 0.22^{a}$ & $4.68 \pm 0.05^{b}$ \\
\hline & $20-30 \mathrm{~cm}$ & $6.21 \pm 0.04^{a}$ & $6.06 \pm 0.18^{a}$ & $6.28 \pm 0.21^{a}$ & $4.65 \pm 0.03^{b}$ \\
\hline \multirow[t]{4}{*}{$D_{b}\left(g \cdot \mathrm{cm}^{-3}\right)$} & & $1.27 \pm 0.03^{a}$ & $1.37 \pm 0.06^{a}$ & $1.15 \pm 0.08^{a}$ & $1.25 \pm 0.05^{a}$ \\
\hline & $0-10 \mathrm{~cm}$ & $1.11 \pm 0.04 \mathrm{bcd}$ & $1.14 \pm 0.07$ bcd & $0.94 \pm 0.12^{d}$ & $0.96 \pm 0.07 \mathrm{~cd}$ \\
\hline & $10-20 \mathrm{~cm}$ & $1.38 \pm 0.06^{a b}$ & $1.32 \pm 0.08^{a b c}$ & $1.26 \pm 0.14 \mathrm{bcd}$ & $1.36 \pm 0.06^{a b}$ \\
\hline & $20-30 \mathrm{~cm}$ & $1.31 \pm 0.04^{a b c}$ & $1.65 \pm 0.12^{a}$ & $1.29 \pm 0.14^{\mathrm{abcd}}$ & $1.44 \pm 0.06^{a b}$ \\
\hline \multirow[t]{4}{*}{$\mathrm{TC}(\%)$} & & $1.25 \pm 0.09^{c}$ & $2.09 \pm 0.22 \mathrm{ab}$ & $2.76 \pm 0.25^{a}$ & $2.03 \pm 0.35^{b}$ \\
\hline & $0-10 \mathrm{~cm}$ & $1.93 \pm 0.13^{\mathrm{de}}$ & $3.21 \pm 0.46 \mathrm{bc}$ & $4.21 \pm 0.74 a b$ & $4.43 \pm 0.94^{a}$ \\
\hline & $10-20 \mathrm{~cm}$ & $1.03 \pm 0.13^{\text {def }}$ & $1.73 \pm 0.37$ def & $2.03 \pm 0.29 \mathrm{~cd}$ & $0.90 \pm 0.10$ def \\
\hline & $20-30 \mathrm{~cm}$ & $0.80 \pm 0.08$ ef & $1.34 \pm 0.33$ def & $1.88 \pm 0.48 \mathrm{~cd}$ & $0.66 \pm 0.15^{f}$ \\
\hline \multirow[t]{3}{*}{$\mathrm{TN}(\%)$} & & $0.14 \pm 0.01^{b}$ & $0.18 \pm 0.02 a b$ & $0.21 \pm 0.02^{a}$ & $0.16 \pm 0.02^{b}$ \\
\hline & $0-10 \mathrm{~cm}$ & $0.20 \pm 0.01^{b c}$ & $0.27 \pm 0.04^{a b}$ & $0.31 \pm 0.05^{a}$ & $0.30 \pm 0.08^{a}$ \\
\hline & $10-20 \mathrm{~cm}$ & $0.12 \pm 0.01 \mathrm{~cd}$ & $0.16 \pm 0.03 \mathrm{~cd}$ & $0.16 \pm 0.02 \mathrm{~cd}$ & $0.09 \pm 0.02^{d}$ \\
\hline
\end{tabular}

a,b,c,d letters indicate significant differences between sites at $a=0.05$. 


\begin{tabular}{|llllll|}
\hline & Depth & ARP & BR & JJM & MN \\
\hline & $20-30 \mathrm{~cm}$ & $0.10 \pm 0.01^{\mathrm{d}}$ & $0.12 \pm 0.03^{\mathrm{cd}}$ & $0.15 \pm 0.02^{\mathrm{cd}}$ & $0.07 \pm 0.02^{\mathrm{d}}$ \\
\hline $\begin{array}{l}\text { TC Stock }\left(\mathbf{k g} \cdot \mathbf{m}^{-}\right. \\
\text {2) }\end{array}$ & $\mathbf{0 - 1 0 \mathrm { cm }}$ & $2.12 \pm 0.24^{\mathrm{b}}$ & $3.49 \pm 0.61^{\mathrm{a}}$ & $3.50 \pm 0.55^{\mathrm{a}}$ & $3.67 \pm 0.45^{\mathrm{a}}$ \\
\hline & & & & \\
\hline a,b,c,d letters indicate significant differences between sites at a $=0.05$. & & \\
\hline
\end{tabular}

Measurements of wetland soil physicochemistry in NOVA are comparable to some, but not all, previous studies at similar sites (Table 3). For example, this study's $D_{b}$ measurements trended higher than historic measurements for both the Piedmont and Coastal Plain: while Axt and Walbridge (1999) measured $D_{b}$ of Piedmont forested wetlands to be $1.26 \mathrm{~g} \cdot \mathrm{cm}^{-3}$, we measured $D_{b}$ to be on average higher, with values of 1.27 $\pm 0.03 \mathrm{~g} \cdot \mathrm{cm}^{-3}$ at ARP and $1.37 \pm 0.06 \mathrm{~g} \cdot \mathrm{cm}^{-3}$ at BR; they similarly measured $D_{b}$ to be lower $\left(1.05 \mathrm{~g} \cdot \mathrm{cm}^{-3}\right)$ than found in this study (JJM: $1.15 \pm 0.08 \mathrm{~g} \cdot \mathrm{cm}^{-3}$; MN: $1.25 \pm 0.05 \mathrm{~g} \cdot \mathrm{cm}^{-3}$ ) (Table 2). When compared to Ahn et al.'s (2009) measurements of soil physicochemistry at MN, current measurements indicate that MN has developed significantly more alkaline soil pH (4.09 [historical]; 4.57 [current]) and higher $\mathrm{D}_{\mathrm{b}}\left(0.45 \mathrm{~g} \cdot \mathrm{cm}^{-3}\right.$ [historical]; $1.25 \mathrm{~g} \cdot \mathrm{cm}^{-3}$ [current]) (Ahn et al. 2009). A 2013 study found BR soils to be more alkaline and with higher moisture than found here and may simply be a result of site hydrologic variability (Peralta et al. 2013). Overall, the four sites' soil properties fell within ranges for riparian system wetlands identified in the literature review, although $D_{b}$ trended higher (Table 3). 
Table 3

Soil physicochemical and nutrient (carbon and nitrogen) properties as reported from selected references. FM:

Freshwater marshes; FS: Freshwater swamp; RS: Riparian systems.

\begin{tabular}{|c|c|c|c|c|c|c|}
\hline $\begin{array}{l}\text { Wetland } \\
\text { type }\end{array}$ & $\begin{array}{l}\text { Soil } \\
\text { pH }\end{array}$ & $\begin{array}{l}D_{b} \\
\left(g \cdot \mathrm{cm}^{-}\right. \\
3)\end{array}$ & $\begin{array}{l}\text { Total C } \\
\text { (\%) }\end{array}$ & $\begin{array}{l}\text { Total N } \\
\text { (\%) }\end{array}$ & $\mathrm{n}$ & Source \\
\hline $\mathrm{FM}^{*}$ & 5.60 & 1.07 & - & - & 3 & Ahn and Jones 2013 \\
\hline FS & - & 0.43 & 1.73 & - & 42 & Ausseil et al. 2015 \\
\hline RS & 4.97 & 1.26 & - & - & 3 & Axt and Walbridge 1999 (Piedmont) \\
\hline RS & 4.72 & 1.05 & - & - & 3 & $\begin{array}{l}\text { Axt and Walbridge } 1999 \text { (Coastal } \\
\text { Plain) }\end{array}$ \\
\hline FS & 5.67 & 0.11 & 42.85 & 2.10 & 5 & Bridgham et al. 1998 \\
\hline RS & - & 1.28 & - & 0.12 & 3 & Craft and Chiang 2002 \\
\hline RS & - & 1.01 & 2.17 & - & 8 & D’Angelo 2005, D’Angelo et al. 2005 \\
\hline $\mathrm{FM}^{*}$ & 4.95 & 1.29 & - & 0.17 & 4 & Dee and Ahn 2012 \\
\hline FM & 8.76 & 0.98 & - & - & 20 & Galatowitsch and van der Valk 1996 \\
\hline RS & - & 0.78 & 8.48 & - & 13 & Hansen and Nestlerode 2014 \\
\hline RS & 4.83 & - & - & 1.45 & 3 & Johns et al. 2004 \\
\hline FS & - & 0.71 & - & - & 2 & Korol and Noe 2020 \\
\hline RS & 6.85 & - & - & - & 1 & Liggett et al. 2019 \\
\hline FS & 6.24 & 0.95 & - & 0.30 & 1 & Nair et al. 2001 \\
\hline RS & 5.62 & 0.88 & 2.89 & 0.17 & 1 & Noe 2011 \\
\hline RS & 4.90 & 1.25 & - & 0.32 & 2 & Peralta et al. 2013 \\
\hline FM & 7.33 & - & - & 0.84 & 1 & Rodríguez-Murillo et al. 2011 \\
\hline RS & 5.45 & - & 3.53 & 0.28 & 2 & Stolt et al. 2000 \\
\hline RS & 5.30 & - & - & - & 1 & Taylor and Middleton 2004 \\
\hline FS & 5.29 & - & 5.24 & 0.52 & 1 & Yoon et al. 2015 \\
\hline
\end{tabular}

The effects of between- and within-site variation may explain discrepancies. While certain properties may be explained by factors of the broader watershed and/or landscape such as watershed urbanization and physiographic province, high within-site and within-plot variability as indicated by large standard errors highlights the vast heterogeneity of collected samples that may be more dependent on smaller-scale 
variability in microtopography, vegetation, and hydrology across a site. Nonetheless, significant differences in soil properties between sites were determined and indicate the capacity to distinguish wetland sites by physicochemistry.

\section{Soil Carbon and Nitrogen}

Compared to the depth intervals $10-20 \mathrm{~cm}, 20-30 \mathrm{~cm}$ and $10-30 \mathrm{~cm}$, the majority of soil carbon and nitrogen came from the top $10 \mathrm{~cm}$ for all sites ( $p<0.05$ ); specifically, $54.6 \%$ of TC and $50.1 \%$ of TC stocks from 0 to 30 $\mathrm{cm}$ were derived from the top $10 \mathrm{~cm}$. When compared to TC and TC stocks of other studies investigating freshwater wetland ecosystems (Table 3), comparable soil carbon and nitrogen content at BR were reported in a 2013 study (Peralta et al. 2013); however our study revealed lower TC percentages and stocks (Table 2). Similar to previous studies, TC percentages indicated in Table 2 suggest that all studied sites are predominantly mineral soils, as none approached the organic soil TC range of 12-20\% (Mitsch and Gosselink 2015).

All soils, except those at ARP, nonetheless included TC percentages greater than $2.0 \%$, supporting the notion that such soils support biogeochemical reactions atypical to upland aerobic soils. While wetland mineral soils can contain carbon percentages closer to $5-10 \%$, it is possible these sites have higher percentages of mineral materials like iron and silica due to all sites receiving surface runoff and/or occurring in close proximity to rivers or streams which are capable of transporting sediments to the top of the soil profile (Hogan and Walbridge 2007). Plots with hydrology more congruent to that of wetlands-e.g., the hollows at MN, a semipermanently flooded floodplain section of JJM, and a flooded depression at the bottom of a hill at BRconsisted of soils with $\mathrm{TC}>5 \%$, whereas plots with less frequent flooding/ponding-e.g., the hummocks at $\mathrm{MN}$, a drier portion of the floodplain at ARP, and a low-moisture plot next to a creek at BR-consisted of soils with $\mathrm{TC}<5 \%$. As above- and below-ground plot vegetation biomass likely played a large part in soil carbon contents and stocks, future research may desire to incorporate vegetation biomass as a factor to consider in teasing apart soil carbon differences.

With respect to wetland sites, TC was significantly different between and within sites $(p<0.05)$, indicating high spatial heterogeneity despite general similarities in ecosystem functions. Both TC and TN were highest at JJM $(2.76 \pm 0.25 \% ; 0.21 \pm 0.02 \% ; p<0.05)$, which could be due the consistent presence of a hydrologic regime more conducive to wetland ecosystem functions such as seasonally anoxic conditions responsible for reducing organic matter decomposition rates. Furthermore, the combination of more polluted run-off at JJM and prolonged oxidizing conditions during certain periods of the year may lead to nitrogen mineralization and nitrification, introducing nitrogen to soils at a faster rate than denitrification can remove it. Conversely, ARP soils hosted the lowest TC and TN of the sites $(1.25 \pm 0.09 \% ; 0.14 \pm 0.01 \% ; p<0.05)$, with both nutrients being most concentrated within the top $10 \mathrm{~cm}$ of soil $(3.58 \pm 0.32 \% ; 0.27 \pm 0.02 \% ; \mathrm{p}<0.05)$ (Table 2). This result supports the established inverse relationship between carbon content and depth from the surface and was identified for all sites (Van Dam et al. 1997).

Analogous to TC, ARP had significantly lower TC stocks than all other sites $\left(2.12 \pm 0.24 \mathrm{~kg} \bullet \mathrm{m}^{-2} ; \mathrm{p}<0.05\right)$; however, as opposed to JJM, BR had the highest TC stocks ( $\left.3.49 \pm 0.61 \mathrm{~kg} \cdot \mathrm{m}^{-2} ; \mathrm{p}<0.05\right)$. Microtopographic controls on hydrology and vegetation, as well as distinct geomorphic evolutions and dynamics, may explain 
how different plots of the same wetland may consist of distinct characteristics of TC and TC stocks; for example, depressions are more prone to receive hydrologic inputs from rainfall and runoff, and will retain inundation from periodic river flooding unlike higher hummock areas (Korol and Noe 2020).

\section{Soil carbon storage and physicochemistry as affected by soil depth, physiographic province, and urbanization degree}

Understanding urban wetland physicochemistry and carbon storage potential in the context of NOVA's Piedmont and Coastal Plain has implications for evaluating and managing their ecosystem services through land and waterscape planning, development, and management (Palta et al. 2017; Zedler and Leach 1998). The three-way ANOVA (Table 4) was able to build upon previously established trends and relationships to tease apart effects of, and interactions between, soil depth, physiographic province, and urbanization degree integral to such a comprehensive understanding.

Table 4

Three-way Analysis of Variance (ANOVA) of soil carbon and physicochemical properties by three factors: soil depth (i.e., $0-10 \mathrm{~cm}$ and $10-30 \mathrm{~cm}$ ), physiography (i.e., Piedmont or Coastal Plain) and degree of urbanization (i.e., urban or non-urban), and by including interaction terms. GSM = gravimetric soil moisture (\%); $\mathrm{D}_{\mathrm{b}}=$ bulk

$$
\text { density }\left(\mathrm{g} \cdot \mathrm{cm}^{-3}\right) ; \mathrm{TC}=\text { total carbon (\%); TN = total nitrogen (TN) }
$$

\begin{tabular}{|c|c|c|c|c|c|c|c|c|c|c|}
\hline & \multicolumn{2}{|l|}{ GSM } & \multicolumn{2}{|l|}{$D_{b}$} & \multicolumn{2}{|l|}{$\mathrm{pH}$} & \multicolumn{2}{|l|}{ TC } & \multicolumn{2}{|l|}{ TN } \\
\hline & $\mathrm{F}$ & Sig & $\mathrm{F}$ & Sig & $\mathrm{F}$ & Sig & $\mathrm{F}$ & Sig & $\mathrm{F}$ & Sig \\
\hline Depth & 9.84 & ** & 9.26 & ** & 0.23 & NS & 33.03 & $\star *$ & 27.74 & ** \\
\hline Urbanization & 6.32 & * & 1.51 & NS & 20.01 & $\star \star$ & 0.02 & NS & 0.07 & NS \\
\hline $\begin{array}{l}\text { Physiographic } \\
\text { Province }\end{array}$ & 3.44 & NS & 2.02 & NS & 33.23 & $\star \star$ & 8.06 & $\star *$ & 1.42 & NS \\
\hline $\begin{array}{l}\text { Depth X } \\
\text { Urbanization }\end{array}$ & 0.18 & NS & 0.86 & NS & 0.52 & NS & 2.13 & NS & 1.13 & NS \\
\hline $\begin{array}{l}\text { Depth X } \\
\text { Physiographic } \\
\text { Province }\end{array}$ & 0.94 & NS & 0.29 & NS & 0.03 & NS & 4.52 & * & 1.76 & NS \\
\hline $\begin{array}{l}\text { Urbanization } \\
\text { X } \\
\text { Physiographic } \\
\text { Province }\end{array}$ & 0.27 & NS & 0.01 & NS & 21.45 & $* *$ & 10.34 & $\star *$ & 7.39 & $\star \star$ \\
\hline $\begin{array}{l}\text { Depth X } \\
\text { Urbanization } \\
\text { X } \\
\text { Physiographic } \\
\text { Province }\end{array}$ & 0.03 & NS & 0.45 & NS & 0.01 & NS & 0.30 & NS & 0.05 & NS \\
\hline
\end{tabular}


Between urbanized and non-urbanized sites, GSM and pH, but not TC or TN, significantly differed. Urban sites had significantly higher GSM (50.44 $\pm 2.68 \%)$ and soil pH $(6.03 \pm 0.07)$ compared to the non-urban sites, and also had significantly lower soil $D_{b}\left(1.23 \pm 0.05 \mathrm{~g} \bullet \mathrm{cm}^{-3} ; 1.39 \pm 0.04 \mathrm{~g} \bullet \mathrm{cm}^{-3} ; \mathrm{p}<0.05\right)$. There were no significant differences in TC or TC stocks based on degree of urbanization $(p>0.05)$, although urban wetland soils had slightly lower TC (3.07 $\pm 0.31 \%)$ and TC stocks $\left(2.81 \pm 0.35 \mathrm{~kg} \bullet \mathrm{m}^{-2}\right)$ than non-urban wetland soils (TC: $3.82 \pm 0.40 \%$; TC stocks: $3.58 \pm 0.28 \mathrm{~kg} \cdot \mathrm{m}^{-2}$ ) (Table 2).

Previous studies have determined that urbanization increase carbon and nitrogen loads of urban wetlands (Bae and Ryu 2015; Ehrenfeld 2000; Palta et al. 2017), which may be reconciled with our results due to biogeochemical processes by which nutrient loads are incorporated into soil stocks. As flooding can significantly influence ecological functions of wetlands, the impervious surface coverage within an urbanized watershed should affect the elemental composition of wetland soils (Bai et al. 2005). Our urbanized and nonurbanized wetlands may have shown similarities in TC stocks despite differences in carbon loads due to the more extensive historical accumulation of carbon and stabilization of carbon stocks within non-urbanized sites. Additionally, variability in sedimentation accumulation, hydrologic regime, or vegetation community at the plot level can account for differences-or lack thereof-in soil carbon content despite similarities in landscape characterization (Adame et al. 2020; Bridgham et al. 1998; Chmura et al. 2003). In addition to addressing these factors, future research could better define this study's uncertainties in the relationship between urbanization and soil carbon by focusing on the study design: i.e., increasing the number of wetland sites per combination of urbanization degree and physiographic province, including sites within watersheds of not only similar \%ISC but also patterns of \%ISC, and limiting variability in plot and site hydrologic regimes. Nevertheless, the lack of significant difference in carbon storage between urban and non-urban sites suggests that urban wetlands can fairly function comparably to wetlands in less disturbed watersheds in storing carbon within their soils.

While depth was found to have a significant effect on GSM, TC, TN, and $D_{b}$, no significant interaction between depth and urbanization was found ( $p<0.01$; Table 4). Independent of urbanization degree, the top $10 \mathrm{~cm}$ had significantly higher TC and TN compared to the deeper depth layers, attributed to a moderate negative linear correlation between $D_{b}$ and TC $(r=-0.61)$, and $D_{b}$ and TN $(r=-0.58)$. Previous studies have concluded that TN and TC decrease with soil depth because of increasing $D_{b}$ and reductions in SOC due to lessened inputs of carbon from organic additions and translocations (Bai et al. 2005; Bridgham et al. 1998; Collins and Kuehl 2001; Gathumbi et al. 2005; Ma et al. 2016; Mitsch and Gosselink 2015; Sigua et al. 2004; Stephens et al. 2015).

A significant interaction was found between urbanization degree and physiographic province for both $\mathrm{pH}$ and TC (Table 4): while urbanized sites had significantly higher $\mathrm{pH}(\mathrm{p}<0.05)$, differences were much more pronounced in the Coastal Plain (i.e., between MN and JJM). Furthermore, while no significant difference in TC was found between urbanized and non-urbanized sites, a comparison after separating by physiographic province introduced a positive effect of urbanization on soil carbon content for the Coastal Plain but a negative effect for the Piedmont $(p<0.05)$ : while JJM $(C P-U)$ had significantly higher TC $(2.76 \pm 0.25 \%)$ than $\mathrm{MN}(\mathrm{CP}-\mathrm{N} ; 2.03 \pm 0.35 \%)$, BR $(\mathrm{P}-\mathrm{N})$ had significantly higher TC $(2.09 \pm 0.22 \%)$ than ARP (P - U; 1.25 $\pm 0.09 \%$ ) (Table 2). TC stocks followed a slightly different pattern, with significantly higher TC stocks in the 
non-urbanized site for the Piedmont (3.49 \pm 0.61 [BR]; $2.12 \pm 0.24$ [ARP]; $\mathrm{p}<0.05)$ but similar TC stocks between urbanization degree in the Coastal Plain (urbanized [JJM]: $3.50 \pm 0.55$; non-urbanized [MN]: $3.67 \pm$ $0.45 ; p>0.05$ ) (Table 2).

Additionally, both soil TC and TN contents were significantly higher at the urban Coastal Plain site, JJM, than the urban Piedmont site, ARP $(p<0.05)$. While such a result may be more tied to specific site properties independent of urbanization degree, it may indicate that hydrologic impacts of urbanization, especially sites created to act as hydrologic sinks (i.e., a generic bathtub design) like JJM, can improve carbon storage throughout the top $30 \mathrm{~cm}$ of soil when soil horizonation is developed enough. This interpretation may also explain why urbanization had a positive effect on TC and TC stocks for Coastal Plain sites, as JJM (CP-U) has been created with the purpose of developing wetland functions over time efficiently and effectively.

The interaction between physiographic province and urbanization can also be better understood by examining differences in soil properties by physiographic province alone. Physiographic province was determined to play a greater role in TC than urbanization degree: soil carbon content did not differ between urbanization degrees but did differ between the Piedmont and Coastal Plain ( $p<0.05)$. Between 0 and $10 \mathrm{~cm}$, but not 10 to $20 \mathrm{~cm}$ or 20 to $30 \mathrm{~cm}$, Coastal Plain sites had significantly higher TC than Piedmont sites $(4.32 \pm 0.41 \% ; 2.57 \pm 0.22 \%$; $p$ <.01); analogously, the Coastal Plain sites had higher TC content in all depth layers.

The Piedmont and Coastal Plain provinces have different physiochemical properties which may explain carbon content differences: in addition to soil $D_{b}$ being significantly lower $(p<.05)$ at the Piedmont sites $(1.21$ $\left.\pm 0.04 \mathrm{~g} \cdot \mathrm{cm}^{-3}\right)$ and GSM being significantly higher $(p<0.05)$ at Coastal Plain sites $(48.79 \pm 3.14 \%$ [CP]; 38.51 $\pm 1.43 \%[\mathrm{P}])$, Piedmont soils host higher clay percentages, which can influence the stabilization of organic carbon within the soil and result in greater TC in soils with more clay (Causarano et al. 2008). Despite the lack of significant difference in TC or TC stocks based on urbanization degree $(p>0.05)$, physiography may explain why average TC percentages in the top $10 \mathrm{~cm}$ were more similar for Coastal Plain sites (MN [N]; JJM [U]; p > $0.05)$ than for Piedmont sites (BR [N]; ARP [U]) ( $<<0.05$; Table 2). It appears that less mature urban wetlands may be more capable of mirroring natural wetland carbon storage in areas with low clay content. Nonetheless, there was no significant difference between TC stocks based on physiographic province such that TC differences by physiographic province may be less relevant for land management decisions $(p>0.05)$. Further research may warrant a better understanding of this mechanism.

The interplay between urbanization and physiographic province in NOVA is important to consider in urban planning and land management issues, as both landscape position and land use/landcover patterns can impact the carbon stocks of wetlands (Craft and Chiang 2002; Craft et al. 2018). NOVA's current and future extent of urbanization is inextricably linked to physiographic province, as the Coastal Plain began to transition from natural and agricultural to rural in the 19th century, whereas urbanization began in the Piedmont during the 1970s (Painter 2018). Changes to carbon and nitrogen cycling begin after initial urban disruption or construction, therefore alterations to soil physicochemistry and carbon storage can act as an indicator of not just present urbanization, but record when urbanization began (Trammell et al. 2020). Like ARP, wetland areas surrounded by relatively recently urbanized landcover in the Piedmont may not have the impacts of urbanization captured within long-term soil properties, whereas wetland areas surrounded by more stable landcover changes in the Coastal Plain, like JJM, may better exhibit stable properties. Nonetheless, the 
deliberate construction of JJM to function as a wetland cannot be ignored in this study's results and indicates that wetland construction in an urban area can be successful at mirroring wetland functions of a non-urban wetland.

\section{Correlations and regressions among soil properties and soil carbon}

While similarities in soil carbon content and stocks between urban and non-urbanized wetlands may be attributable to confounding factors at smaller spatial scales, additional considerations of soil physicochemical properties may more pointedly aid urban planners and designers by acting as better indicators of soil carbon storage potential. Soil physicochemical properties like $D_{b}, G S M$, and pH are not only easy to measure, but can better capture plot-level characteristics related to carbon storage potential than can more generalized landscape characteristics (Collins and Kuehl 2001).

Hydrologic regime is theoretically related to the capacity for a wetland to accumulate carbon, and GSM-a soil property that that may vary depending on rainfall or season but which is inevitably linked to soil water retention-was found to be correlated with TC $(r=0.68 ; p<0.01)$ (Ahn and Peralta 2009). Linear regression indicated that $47 \%$ of TC variability could be estimated by GSM using the equation TC $=0.047 \cdot G S M-0.005$ $\left(R^{2}=0.47 ; p<0.05 ;\right.$ Fig. 2a), with increases in soil moisture relating to increases in carbon content.

Nonetheless, the relationship between GSM and TC stocks was insignificant, with less than $1 \%$ of TC stock variability attributable to GSM ( $p>0.05$; Fig. $2 b$ ). TC is known to correlate with GSM for soils with high TC and GSMs that can exceed 300\% (Verry et al. 2011). As calculated GSM for the sites of this study did not exceed $80 \%$, it is possible that an inclusion of soils with a greater range in both TC and GSM would have resulted in a stronger positive relationship between GSM and TC and/or TC stocks. The explanatory power of GSM is modest, but indicates that, in conjunction with $D_{b}$ measurements, GSM can provide insight into carbon storage potential of a wetland.

Like GSM, $D_{b}$ shared a moderately strong negative correlation with both TC and TN $(r=-0.62 ; r=-0.61 ; p<0.05$ for both). The regression model for $T C$ from $D_{b}$ resulted in a negative slope $(-2.86 ; p<0.05)$ and a modest regression coefficient $\left(R^{2}=0.39 ; p<0.05 ;\right.$ Fig. $\left.2 c\right)$, suggesting that small increases in bulk density can have significant but variable impacts on soil carbon content. The incorporation of $D_{b}$ into the metric of carbon storage potential via TC stocks rendered a regression model that was much weaker, with $D_{b}$ unable to provide any explanatory power for TC stocks $\left(R^{2}=0.002 ; p>0.05\right.$; Fig. $\left.2 d\right)$. The inverse relationship between $D_{b}$ and nutrient concentrations was expected: $D_{b}$ is known to relate positively to the processes of carbon and nitrogen mineralization such that increasing $\mathrm{D}_{\mathrm{b}}$ would be related to a decrease in soil TC and TN (Bridgham et al. 1998). Additionally, $D_{b}$ decreases with increasing organic content in organic and mineral soils as observed in other studies (Ahn and Jones 2013; Ausseil et al. 2015; Ruehlmann and Körschens 2009; Verry et al. 2011); despite TC, rather than organic carbon, being measured in this study, our data can be suggested to support this relationship given the very low amount of inorganic carbon known to exist within Piedmont and Coastal Plain soils based upon previous studies. Finally, a negative linear relationship was apparent between soil pH and soil nutrient concentrations only for ARP (TC: $r=-0.35$ ) and JJM (TC: $r=-0.55$; TN: $r=-0.55$ ), but not BR or $\mathrm{MN}$. More mature wetlands are known to have more feedback systems capable of buffering soil pH, and 
circumneutral pHs are more common (Mitsch and Gosselink, 2015); thus, a more prominent correlation between soil pH and TC and TN may be an indicator of relatively younger ecosystems at ARP and JJM.

Soil physiochemical property correlations can be utilized to explain how landscape-scale factors of physiography and urbanization impact wetland soils more coherently and holistically. Urbanization may only directly impact a singular soil property-e.g., soil disturbances which impacts $D_{b}$, or hydrologic changes which increase soil inundation during flooding events-at a particular site, but may indirectly impact other properties related to wetland function: altered $\mathrm{D}_{\mathrm{b}}$ will alter $\mathrm{C}$ burial, $\mathrm{N}$ loading limits, and $\mathrm{C}$ loading (Collins and Kuehl 2001; Cui et al. 2005; Faulkner 2004; Palta et al. 2014; Suchy et al. 2019). A failure to demonstrate a direct difference of carbon content by degree of urbanization in this study does not discount the influence of urbanization, as we found a difference in GSM by degree of urbanization, and this difference affects TC through an existing regression between GSM and TC (Fig. 2a). Similarly, we found a difference in $D_{b}$ based on urbanization degree, which indirectly affects TC through the modest regression between $D_{b}$ and TC (Fig. 2C). Therefore, to understand the scope of influence over the carbon storage potential of wetlands, soil physiochemical property correlations need to be assessed.

\section{Conclusion}

While forested wetlands in urban areas may be situated in diverse environments with respect to geomorphology, physiography, and soil physicochemistry, our results indicate that urban wetlands can host carbon stocks comparable to those in non-urban areas. Urban wetlands were more capable of mirroring the carbon storage potential of non-urban wetlands in the Coastal Plain than in the Piedmont, suggesting more concerted planning and/or management of wetlands in urban and urbanizing watersheds of the Virginia Piedmont may be necessary to augment carbon storage potential. Our results also indicated that, while more wetland soil development can increase overall carbon storage, the top $10 \mathrm{~cm}$ of soils is the most capable of storing carbon and most influential in providing ecosystem services to cities and suburbs.

Finally, while we determined that watershed urbanization did not result in distinct TC or TC stocks within the top $10 \mathrm{~cm}$ of NOVA forested wetlands, the indirect signature of urbanization on wetland ecosystem functions was more apparent through links between urbanization and soil physicochemical properties. In conjunction with the modest capabilities of both $D_{b}$ and $G S M$ to predict TC (i.e., $R^{2}=0.39 ; R^{2}=0.47$ ), significant differences in $D_{b}$ and GSM between urbanization degrees indicate that TC may be traceable to urbanization degree when studied in conjunction with soil physicochemistry. Continuous monitoring of soil physicochemical and carbon properties at various sites across an urbanizing landscape may be required before drawing conclusions on the significance of soil carbon storage in urban forested wetlands as they relate to climate change mitigation strategies in cities.

\section{Declarations}

\section{Funding}

The authors did not receive financial support from any organization for the submitted work. 


\section{Conflicts of interest/competing interests}

The authors have no conflicts of interest to declare that are relevant to the content of this article.

\section{Availability of data and material}

The data that supports the findings of this study are available from the corresponding author, CA, upon reasonable request.

\section{Code availability}

Not applicable

\section{Authors' contributions}

Kathryn Ledford: Data Collection (Field work), Data Analysis, Writing-Original draft preparation.

Stephanie Schmidt: Data Collection (Field work), Data Analysis, Writing-Reviewing, Editing and Rewriting Changwoo Ahn: Conceptualization and design of the study, Supervision, Data Analysis, Writing-Reviewing, Editing and Rewriting

All authors read and approved the final manuscript.

\section{Acknowledgments}

The authors thank Katrina Napora for her assistance in the lab with processing soil samples for carbon analysis.

\section{Author's information}

Kathryn Ledford: Master's student (ORCID not available); Stephanie Schmidt: Ph.D. candidate (ORCID: 00000001-8235-8820); Changwoo Ahn: Professor (ORCID: 0000-0002-0747-2903), all in Environmental Science and Policy Department, George Mason University

\section{References}

Adame MF, Reef R, Wong VNL, Balcombe SR, Turschwell MP, Kavehei E, Rodríguez DC, Kelleway JJ, Masque P, Ronan M (2020) Carbon and nitrogen sequestration of Melaleuca floodplain wetlands in tropical Australia. Ecosyst 23:454-466

Ahn C, Gillevet PM, Sikaroodi M, Wolf KL (2009) An assessment of soil bacterial community structure and physicochemistry in two microtopographic locations of a palustrine forested wetland. Wetlands Ecol Manage 17:397-407

Ahn C, Jones S (2013) Assessing organic matter and organic carbon contents in soils of created mitigation wetlands in Virginia. Environ Eng Res 18(3):151-156. http://dx.doi.org/10.4491/eer.2013.18.3.151 
Ahn C, Peralta RM (2009) Soil bacterial community structure and physicochemical properties in mitigation wetlands created in the Piedmont region of Virginia (USA). Ecol Eng 35(7):1036-1042.

http://doi.org/10.1016/j.ecoleng.2009.03.005

Ahn C, Schmidt S (2019) Designing wetlands as an essential infrastructural element for urban development in the era of climate change. Sustainability 11. http://doi.org/10.3390/su11071920

Ausseil A-GE, Jamali H, Clarkson BR, Golubiewski NE (2015) Soil carbon stocks in wetlands of New Zealand and impact of land conversion since European settlement. Wetlands Ecol Manage 23:947-961

Axt JR, Walbridge MR (1999) Phosphate removal capacity of palustrine forested wetlands and adjacent uplands in Virginia. Soil Sci Soc Am J 63:1019-1031

Bae J, Ryu Y (2015) Land use and land cover changes explain spatial and temporal variations of the soil organic carbon stocks in a constructed urban park. Landscape Urban Plann 136:57-67

Bai J, Ouyang H, Deng W, Zhu Y, Zhang X, Wang Q (2005) Spatial distribution characteristics of organic matter and total nitrogen of marsh soils in river marginal wetlands. Geoderma 124:181-192

Bartholomew MK, Anderson CJ, Berkowitz J (2019) Soil conditions following hydrologic restoration in Cypress Dome wetlands. Wetlands 39:185-196

Botkin DB, Beveridge CE (1997) Cities as environments. Urban Ecosyst 1:3-19

Bridgham SD, Updegraff K, Pastor J (1998) Carbon, nitrogen, and phosphorus mineralization in northern wetlands. Ecol 79(5):1545-1561

Brigham BA, Montero AD, O'Mullan GD, Bird JA (2018) Acetate additions stimulate $\mathrm{CO}_{2}$ and $\mathrm{CH}_{4}$ production from urban wetland soils. Soil Sci Am J 82:1147-1159

Bruland GL, DeMent G (2009) Phosphorus sorption dynamics of Hawaii's coastal wetlands. Estuaries Coasts 32:844-854

Bruland GL, Richardson CJ (2006) Comparison of soil organic matter in created, restored and paired natural wetlands in North Carolina. Wetlands Ecol Manage 14:245-251 Caldwell PV, Adams AA, Niewoehner CP, Vepraskas MJ, Gregory JD (2005) Sampling

device to extract intact cores in saturated organic soils. Soil Sci Soc Am J 69:2071- 2075

Canedoli C, Ferrè C, Khair DAE, Padoa-Schioppa E, Comolli R (2020) Soil organic carbon stock in different urban land uses: high stock evidence in urban parks. Urban Ecosyt 23:159-171

Causarano HJ, Franzluebbers AJ, Shaw JN, Reeves DW, Raper RL, Wood CW (2008) Soil organic carbon fractions and aggregation in the southern Piedmont and Coastal Plain. Soil Sci Am J 72(1):221-230. https://doi.org/10.2136/sssaj2006.0274 
Chmura GL, Anisfeld SC, Cahoon DR, Lynch JC (2003) Global carbon sequestration in tidal, saline wetland soils. Global Biogeochem Cycles 17(4) https://doi.org/10.1029/2002GB001917

Collins, ME, Kuehl RJ (2001) Organic matter accumulation and organic soils. In: Richardson JL, Vepraskas MJ (eds) Wetland soils: genesis, hydrology, landscapes, and classification. CRC Press, Boca Raton pp 137-162

Craft C, Broome S, Campbell C (2002) Fifteen years of vegetation and soil development after brackish-water marsh creation. Restor Ecol 10(2):248-258

Craft CB, Chiang C (2002) Forms and amounts of soil nitrogen and phosphorus across a longleaf pinedepressional wetland landscape. Soil Sci Soc Am J 66:1713-1721

Cui J, Li C, Trettin C (2005) Modeling biogeochemistry and forest management practices assessing GHGs mitigation strategies in forested wetlands. Environ Model Assess 10:43-53

Dahl TE (2011) Status and trends of wetlands in the conterminous United States 2004 to 2009. US Department of the Interior, Fish and Wildlife Service, Washington, D.C.

D’Angelo EM (2005) Phosphorus sorption capacity and exchange by soils from mitigated and late successional bottomland forest wetlands. Wetlands 25(2):297-305

D’Angelo EM, Karathanasis AD, Sparks EJ, Ritchey SA, Wehr-McChesney SA (2005) Soil carbon and microbial communities at mitigated and late successional bottomland forest wetlands. Wetlands 25(1):162-175

Davidson EA, Janssens IA (2006) Temperature sensitivity of soil carbon decomposition and feedbacks to climate change. Nat 440:165-173

Dee SM, Ahn C (2012) Soil properties plant community development of mitigation wetlands created in the Virginia Piedmont, USA. Environ Manage 37(1):1-14

Duan Z, Zhao S, Zhao L, Duan X, Xie S, Zhang H, Liu Y, Peng Y, Liu C, Wang L (2020) Microplastics in Yellow River Delta wetland: occurrence, characteristics, human influences, and marker. Environ Pollut 258 https://doi.org/10.1016/j.envpol.2019.113232

Ehrenfeld JG (2000) Evaluating wetlands within an urban context. Urban Ecosyst 4:69-85

Ehrenfeld JG, Cutway HB, Hamilton R IV, Stander E (2003) Hydrologic description of forested wetlands in Northeastern New Jersey, USA- an urban/suburban region. Wetlands 23(4):685-700

“Elizabeth Hartwell Mason Neck National Wildlife Refuge." Pamphlet. U.S. Fish and Wildlife Service, August 2014

Faller CR, McCleery RA (2017) Urban land cover decreases the occurrence of a wetland endangered mammal and its associated vegetation. Urban Ecosyst 20:573-580

Faulkner S (2004) Urbanization impacts on the structure and function of forested wetlands. Urban Ecosyst 7:89-106 
Fretwell JD, Williams JS, Redman PJ (1996) National water summary on wetland resources. United States Geologic Survey, Reston, VA.

Friends of Banshee Reeks Nature Preserve (FBRNP) (2020) Banshee Reeks Nature Preserve. https://bansheereeksnp.org Accessed 9 April 2020

Galatowitsch SM, van der Valk AG (1996) Vegetation and environmental conditions in recently restored wetlands in the prairie pothole region of the USA. Vegetatio 126:89-99

Gao J, Ouyang H, Lei G, Xu X, Zhang M (2011) Effects of temperature, soil moisture, soil type, and their interactions on soil carbon mineralization in Zoige alpine wetland, Qinghai-Tibet Plateau. Chin Geogr Sci 21(1):27-35

Gathumbi SM, Bohlen PJ, Graetz DA (2005) Nutrient enrichment of wetland vegetation and sediments in subtropical pastures. Soil Sci Soc Am J 69:539-548

Giannopoulos G, Lee DY, Neubauer SC, Brown BL, Franklin RB (2019) A simple and effective sampler to collect undisturbed cores from tidal marshes. BioRxiv https://doi.org/10.1101/515825

Golubiewski NE (2006) Urbanization increases grassland carbon pools: effects of landscaping in Colorado's front range. Ecol Appl 16:555-571

Gustave W, Yuan Z, Sekar R, Ren Y, Liu J, Zhang J, Chen Z (2019) Soil organic matter amount determine the behavior of iron and arsenic in paddy soil with microbial fuel cells. Chemosphere 237. https://doi.org/10.1016/j.chemosphere.2019.124459

Gutknecht JLM, Goodman RM, Balser TC (2006) Linking soil process and microbial ecology in freshwater wetland ecosystems. Plant Soil 289:17-34

Hansen VD, Nestlerode JA (2014) Carbon sequestration in wetland soils of the northern Gulf of Mexico coastal region. Wetlands Ecol Manage 22:289-303

Hartman WH, Richardson CJ, Vilgalys R, Bruland GL (2008) Environmental and anthropogenic controls over bacterial communities in wetland soils. PNAS 105(46): 17842-17847

Heath RC (1984) Ground-water regions of the United States. U.S. Geological Survey Water-Supply Paper 2242 pp 78

Herrmann DL, Schifman LA, Shuster WD (2018) Widespread loss of intermediate soil horizons in urban landscapes. PNAS 115(26):6751-6755

Holmquist JR, Windham-Myers L, Bliss N, Crooks S, Morris JT, Megonigal JP, Troxler T, Weller D, Callaway J, Drexler J, Ferner MC, Gonneea ME, Kroeger KD, Schile-Beers L, Woo I, Buffington K, Breithaupt J, Boyd BM, Brown LN, Dix N, Hice L, Horton BP, MacDonald GM, Moyer RP, Reay W, Shaw T, Smith E, Smoak JM, Sommerfield C, Thorne K, Velinksy D, Watson E, Grimes KW, Woodrey M (2018) Accuracy and precision of tidal 
wetland soil carbon mapping in the conterminous United States. Nature Scientific Reports 8 https://doi.org/10.1038/s41598-018-26948-7

Homer C, Dewitz J, Jin S, et al (2020) Conterminous United States land cover change patterns 2001-2016 from the 2016 National Land Cover Database. ISPRS J Photogramm Remote Sens 162:184-199. https://doi.org/10.1016/j.isprsjprs.2020.02.019

Johns D, Williams H, Farrish K, Wagner S (2004) Denitrification and soil characteristics of wetlands created on two mine soils in East Texas, USA. Wetlands 24(1):57-67

Johnson KM, Lichter DT (2020) Metropolitan reclassification and the urbanization of rural America. Demography 57:1929-1950. https://doi.org/10.1007/s13524-020-00912-5

JMP®, Version 15 (2019) SAS Institute Inc., Cary, NC, 1989-2019.

Keller JK, Medvedeff KL (2016) Soil organic matter. In: Vepraskas MJ, Craft CB (eds) Wetland soils: genesis, hydrology, landscapes, and classification, $2^{\text {nd }}$ edition. CRC Press, Boca Raton pp 165-188

Korol AR, Noe GB (2020) Patterns of denitrification potential in tidal freshwater forested wetlands. Estuaries Coasts 43:329-346. https://doi.org/10.1007/s12237-019-00663-6

Lacher IL, Ahmadisharaf E, Fergus C, et al (2019) Scale-dependent impacts of urban and agricultural land use on nutrients, sediment, and runoff. Sci Total Environ 652:611-622.

https://doi.org/10.1016/j.scitotenv.2018.09.370

Lal R (2004) Soil carbon sequestration impacts on global climate change and food security. Science 304(5677):1623-1627

Leeds JA, Garrett PB, Newman JM (2009) Assessing impacts of hydropattern restoration of an overdrained wetland on soil nutrients, vegetation and fire. Restor Ecol 17(4):460-469

Liggett C, Knappenberger T, Shaw JN, Brantleyy E, Gamble AV (2019) Comparison of constructed wetlands to a preservation wetland in the Nashville Basin, Tennessee (USA). Wetlands Restor https://doi.org/10.1007/s13157-019-01242-y

Little-Devito M, Mendoza CA, Chasmer L, Kettridge N, Devito KJ (2019) Opportunistic wetland formation on reconstructed landforms in a sub-humid climate: influence of site and landscape-scale factors. Wetlands Ecol Manage 27:587-608

Ma K, Zhang Y, Tang S, Liu J (2016) Spatial distribution of soil organic carbon in the Zoige alpine wetland, Northeastern Qinghai-Tibet Plateau. Catena 144:102-108

Maietta CE, Bernstein ZA, Gaimaro JR, Buyer JS, Rabenhorst MC, Monsaint-Queeney VC, Baldwin AH, Yarwood SA (2019) Aggregation but not organo-metal complexes contributed to $C$ storage in tidal freshwater wetland soils. Soil Sci Soc Am J 83:252-265 
Mitsch WJ, Gosselink JG (2015) Wetlands, $5^{\text {th }}$ edition. John Wiley and Sons, Inc, New York

Moser K, Ahn, C Noe G (2007) Characterization of microtopography and its influence on vegetation patterns in created wetlands. Wetlands 27(4):1081-1097

Nair VD, Graetz DA, Reddy R, Olila OG (2001) Soil development in phosphate-mined created wetlands of Florida, USA. Wetlands 31(2):232-239

“National Water Summary on Wetland Resources.” Report. Water Supply Paper. Washington, D.C., 1996. USGS Publications Warehouse. http://pubs.er.usgs.gov/publication/wsp2425. Accessed 18 November 2020

Nave LE, DeLyser K, Butler-Leopold PR, et al (2019) Effects of land use and forest management on soil carbon in the ecoregions of Maryland and adjacent eastern United States. Forest Ecol Manage 448:34-47. https://doi.org/10.1016/j.foreco.2019.05.072

Noe GB (2011) Measurement of net nitrogen and phosphorus mineralization in wetland soils using a modification of the resin-core technique. Soil Sci Soc Am J 75(2):760-770

Northern Virginia Regional Park Authority (NOVA) (2020) Algonkian Regional Park. NOVAParks https://www.novaparks.com/parks/algonkian-regional-park. Accessed 9 April 2020

Osland MJ, Spivak AC, Nestlerode JA, Lessmann JM, Almario AE, Heitmuller PT, Russell MJ, Krauss KW, Alvarez F, Dantin DD, Harvey JE, From AS, Cormier N, Stagg CL (2012) Ecosystem development after mangrove wetland creation: Plant-soil change across a 20-Year chronosequence. Ecosyst 15:848-866

Painter AA (2018) Rise of a region: a development history of Northern Virginia. https://www.youtube.com/watch?v=0K57Y0mBFAU Accessed July 212020

Palta MM, Ehrenfeld JG, Groffman PM (2014) Denitrification and potential nitrous oxide and carbon dioxide production in brownfield wetland soils. J Environ Qual 42:1507-1517

Palta MM, Grimm NB, Groffman PM (2017) “Accidental” urban wetlands: ecosystem functions in unexpected places. Front Ecol Environ 15(5):248-256

Pasterski MJ, Bellagamba A, Chancellor S, Cunje A, Dodd E, Gefeke K, Hsieh S, Schassburger A, Smith A,Tucker W, Plotnick RE (2020) Aquatic landscape change, extirpations, and introductions in the Chicago region. Urban Ecosyst 23:1277-1288. https://doi.org/10.1007/s11252-020-01001-6

Patenaude T, Smith AC, Fahrig L (2015) Disentangling the effects of wetland cover and urban development on quality of remaining wetlands. Urban Ecosyst 18:663-684

Paul J (2017, March 24) In our backyard: Banshee Reeks, a Virginia treasure. Loudoun Now. http://loudounnow.com/2017/03/24/in-our-backyard-banshee-reeks-a-virginia-treasure/.

Peralta RM, Ahn C, Voytek MA, Kirshtein JD (2013) Bacterial community structure of nirk-bearing denitrifiers and the development of properties of soils in created mitigation wetlands. Applied Soil Ecol 70:70-77 
Phillips RL, Ficken C, Eken M, Hendrickson J, Beeri O (2016) Wetland soil carbon in a watersed context for the prairie pothole region. J Environ Qual 45:368-375

Pouyat RV, Yesilonis ID, Nowak DJ (2006) Carbon storage by urban soils in the United States. J Environ Qual 35:1566-1575

Pulighe G, Fava F, Lupia F (2016) Insights and opportunities from mapping ecosystem services of urban green spaces and potentials in planning. Ecosyst Serv 22:1-10

Reinelt L, Horner R, Azous A (1998) Impacts of urbanization on palustrine (depressional freshwater) wetlandsresearch and management in the Puget Sound region. Urban Ecosyst 2:219-236

Rodríguez-Murillo JC, Almendros G, Knicker H (2011) Wetland soil organic matter composition in a Mediterranean semiarid wetland (Las Tablas de Daimiel, Central Spain): insight into different carbon sequestration pathways. Org Geochem 42:7862-773

Ruehlmann J, Körchens M (2009) Calculating the effect of soil organic matter concentration on soil bulk density. Soil Sci Soc Am J 73: 876-885

Säynäjoki E-S, Korba P, Kalliala E, Nuotio A-K (2018) GHG Emissions Reduction through Urban Planners' Improved Control over Earthworks: A Case Study in Finland. Sustainability 10:1-1

Scanes CG (2018) Chapter 19 - Human Activity and Habitat Loss: Destruction, Fragmentation, and Degradation. In: Scanes CG, Toukhsati SR (eds) Animals and Human Society. Academic Press, pp 451-482

Sigua GC, Griffin J, Kang W, Coleman SW (2004) Wetland conversion to beef cattle pasture: changes in soil properties. J Soils Sediments 4(1):4-10

Stefanakis Al (2019) The role of constructed wetlands as green infrastructure for sustainable urban water management. Sustainability 11(24):6981. https://doi.org/10.3390/su11246981

Stephens K, Sencindiver J, Skousen J (2015) Characteristics of wetland soils impacted by acid mine drainage. Southeast Nat 14(7):40-57

Stolt MH, Genthner MH, Daniels WL, Groover VA, Nagle S, Haering KC (2000) Comparison of soil and other environmental conditions in constructed and adjacent palustrine reference wetlands. Wetlands 20(4):671-683

Suchy AK, Palta MM, Stromberg JC, Childers DL (2019) High potential nitrate removal by urban accidental wetlands in a desert city: limitations and spatiotemporal patterns. Ecosyst https://doi.org/10.1007/s10021019-00465-8

Sunde MG, He HS, Hubbart JA, Urban MA (2018) An integrated modeling approach for estimating hydrologic responses to future urbanization and climate changes in a mixed-use midwestern watershed. J Environ Manage 220:149-162. https://doi.org/10.1016/j.jenvman.2018.05.025 
Tarnocai C (2006) The effect of climate change on carbon in Canadian peatlands. Global Planet Change 53:222-232

Taylor J, Middleton BA (2004) Comparison of litter decomposition in a natural versus coal-slurry pond reclaimed as a wetland. Land Degrad Devel 15:439- 446

Trettin CC, Laiho R, Minkkinen K, Laine J (2006) Influence of climate change factors on carbon dynamics in northern forested peatlands. Canadian J Soil Sci pp 269-280

United Nations. (2019). World urbanization prospects: the 2018 revision (ST/ESA/SER.A/420). Department of Economic and Social Affairs, Population Division. New York: United Nations

Van Dam D, Veldkamp E, Van Breemen N (1997) Soil organic carbon dynamics: Variability with depth in forested and deforested soils under pasture in Costa Rica. Biogeochem 39(3):343-375.

https://www.jstor.org/stable/1469083

Vanderhoof MK, Christensen J, Beal Y-JG, et al (2020) Isolating Anthropogenic Wetland Loss by Concurrently Tracking Inundation and Land Cover Disturbance across the Mid-Atlantic Region, U.S. Remote Sens 12:1464. https://doi.org/10.3390/rs12091464

Verry ES, Boelter DH, Paivanen J, Nichols DS, Malterer T, Gafni A (2011) Physical properties of organic soils. In: Kolka RK, Sebestyen SD, Verry ES, Brooks KN (eds) Peatland biogeochemistry and watershed hydrology at the Marcell Experimental Forest. Taylor and Francis Group, LLC, Boca Raton pp 135-176

Wahlroos O, Valkama P, Mäkinen E, Ojala A, Vasander H, Väänänen V, Halonen A, Lindén L, Nummi P, Ahponen H, Lahti K, Vessman T, Rantakokko K, Nikinmaa E (2015) Urban wetland parks in Finland: improving water quality and creating endangered habitats. Int J Biodivers Sci, Ecosyst Serv Manage 11(91):46-60. https://doi.org/10.1080/21513732.2015.1006681

Wang H, Piazza SC, Sharp LA, Stagg CL, Couvillion BR, Steyer GD, McGinnis TE (2017) Determining the spatial variability of wetland soil bulk density, organic matter, and the conversion factor between organic matter and organic carbon across Coastal Louisiana, U.S.A. J Coastal Res 33(3): 507-517.

Wetlands Studies and Solutions, Inc. (2020, April 20). Julie J. Metz Wetlands Bank. Wetlands. https://www.wetlands.com/julie-metz Accessed 20 April 2020

Xiong X, Grunwald S, Myers DB, Ross CW, Harris WG, Comerford NB (2014) Interaction effects of climate and land use/land cover change on soil organic carbon sequestration. Sci Total Environ 493:974-982

Xue Z, Hou G, Zhang Z, Lyu X, Jiang M, Zou Y, Shen X, Wang J, Liu X (2019) Quantifying the cooling-effects of urban and peri-urban wetlands using remote sensing data: case study of cities of Northeast China. Landscape Urban Plann 182:92-100 https://doi.org/10.1016/j.landurbplan.2018.10.015

Yang L, Chang H, Huang ML (2001) Nutrient removal in gravel- and soil-based wetland microcosms with and without vegetation. Ecol Eng 18:91-105 
Yoon TK, Noh NJ, Han S, Kwak H, Lee W-K, S Y (2015) Small-scale spatial variability of soil properties in a Korean swamp. Landscape Ecol Eng 11:303-312

Zedler JB, Leach MK (1998) Managing urban wetlands for multiple use: Research, restoration, and recreation. Urban Ecosyst 2:189-204

Figures

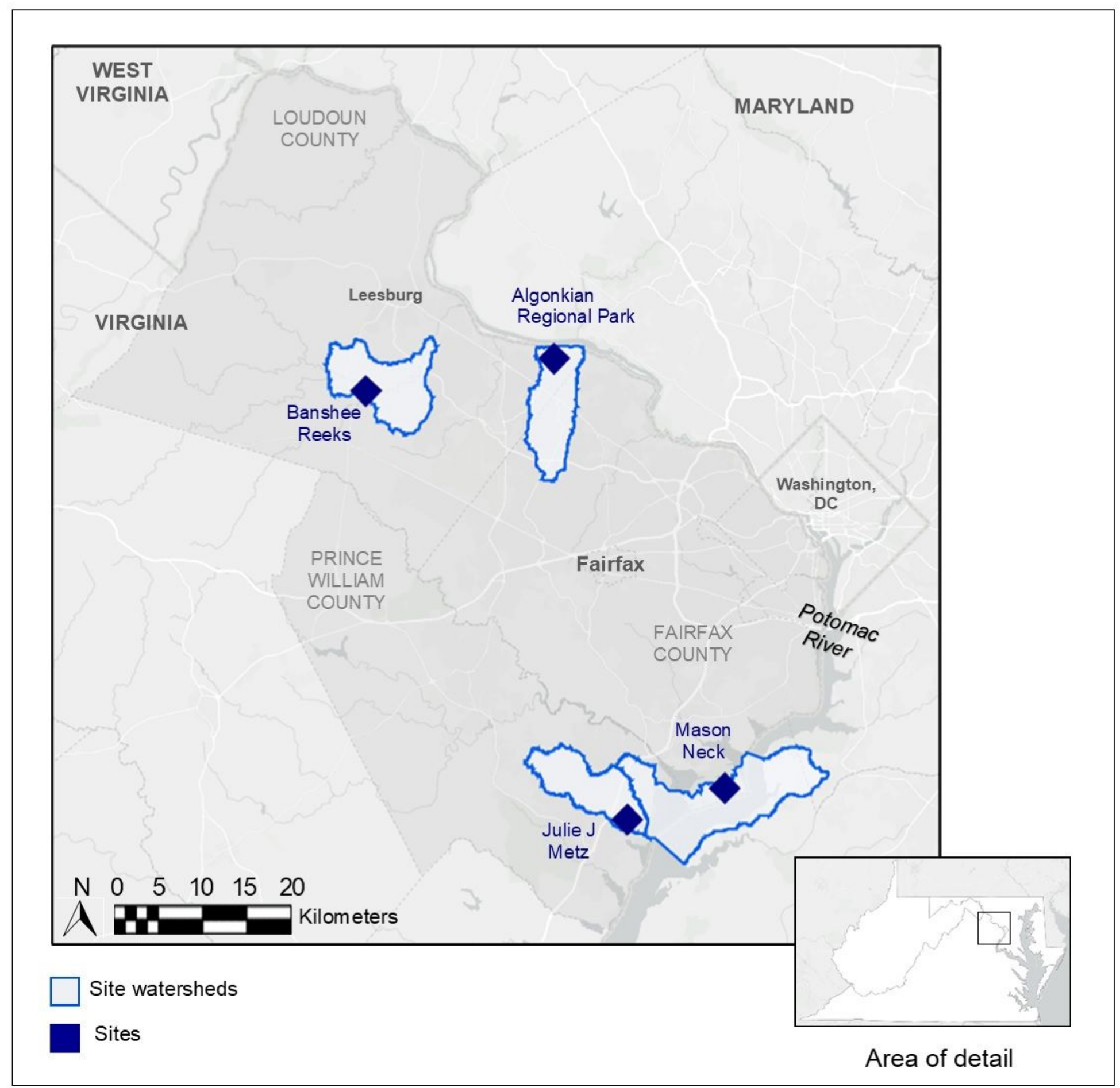

Figure 1 
Study area of Northern Virginia (NOVA), highlighting wetland site locations and their respective watersheds..
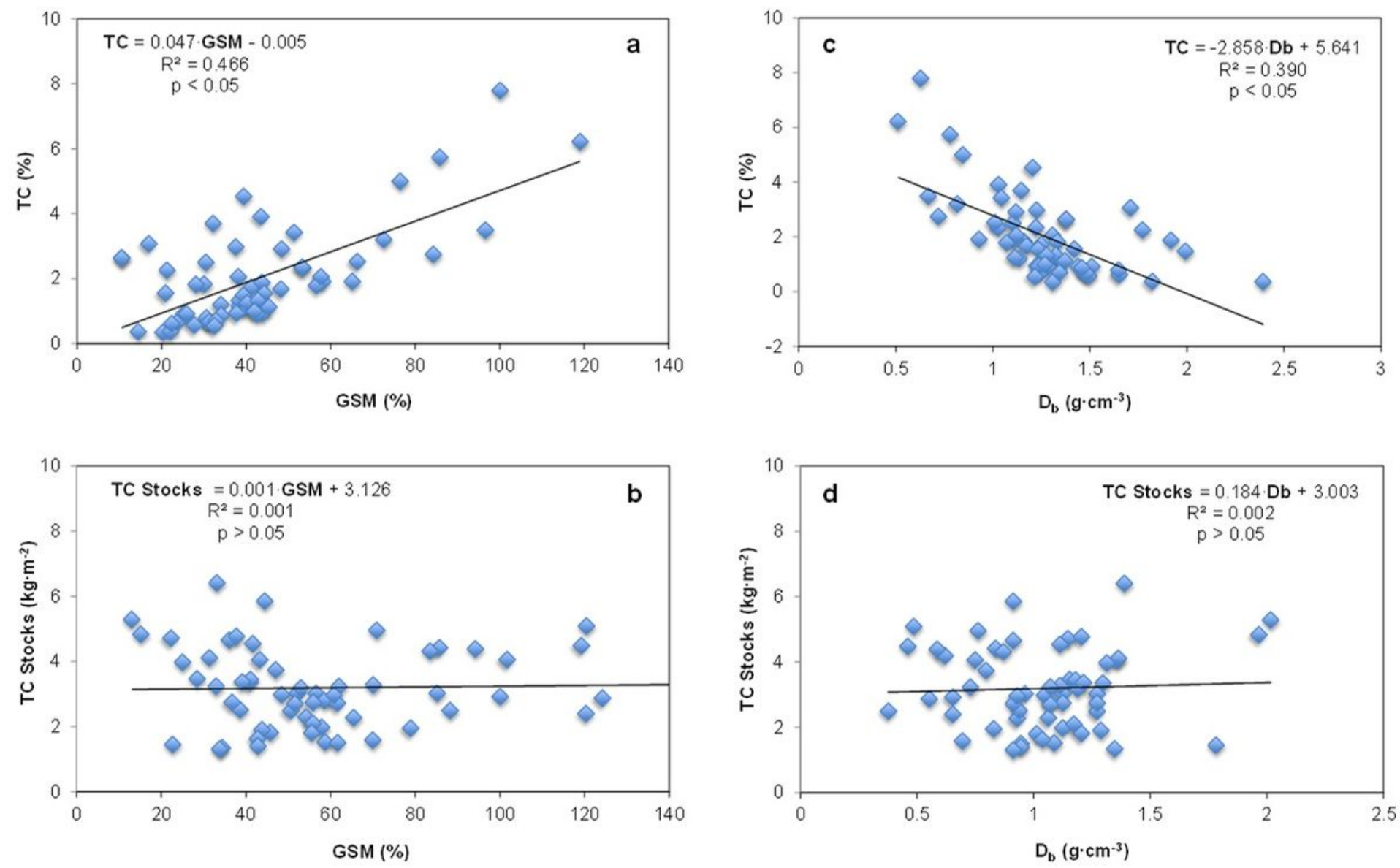

\section{Figure 2}

Regression for total carbon percentages (TC) and total carbon stocks (TC stocks, $\mathrm{kg} \bullet \mathrm{m}-2)$ versus gravimetric soil moisture [GSM] and bulk density [Db]. Regression equations and coefficients are shown within plot areas. 